\title{
NEW BOUNDS FOR SHANNON, RELATIVE AND MANDELBROT ENTROPIES VIA ABEL-GONTSCHAROFF INTERPOLATING POLYNOMIAL
}

\section{SAAD IHSAN Butt, NASIR MEHMOOd, ĐILDA PEČARIĆ AND JosiP PEČARIĆ}

Abstract. The Jensen's inequality has tremendous implications in many fields of modern analysis. It helps computing useful upper bounds for several entropic measures used in information theory. We use discrete and continuous cyclic refinements of Jensen's inequality and extend them from convex to higher order convex function by using new Green functions and AbelGontscharoff interpolating polynomial. As an application of our work, we establish connection among new entropic bounds for Shanon, Relative and Mandelbrot entropies.

Mathematics subject classification (2010): 26A51, 26D15, 26E60, 94A17, 94A15.

Keywords and phrases: $n$-convex function, Abel-Gontscharoff interpolating polynomial, new Green functions, Shannon entropy, relative entropy, Zipf-Mandelbrot entropy.

\section{REFERENCES}

[1] R. P. Agarwal and P. J. Y. Wong, Error Inequalities in Polynomial Interpolation and their Applications, Kluwer Academic Publishers, Dordrecht, (1993).

[2] I. BRnetić, K. A. KHAN AND J. PEČARIĆ, Refinement of Jensen's inequality with applications to cyclic mixed symmetric means and Cauchy means, J. Math. Inequal. 9(4)(2015), 1309-1321.

[3] S. I. ButT AND J. PeČARIĆ, Popoviciu's inequality for n-convex functions, Lap Lambert Academic Publishing ISBN: 978-3-659-81905-6, (2016).

[4] S. I. Butt, J. PeČArić And A. Vukelić, Generalization of Popoviciu type inequalities Via Fink's identity, Mediterr. J. Math. 13(4) (2016), 1495-1511.

[5] S. I. Butt, K. A. Khan And J. PeČArić, Popoviciu Type Inequalities via Green Function and Generalized Montgomery Identity, Math. Inequal. Appl. 18(4) (2015), 1519-1538.

[6] P. Cerone And S. S. Dragomir, Some new Ostrowski-type bounds for the Čebyšev functional and applications, J. Math. Inequal. 8(1) (2014), 159-170.

[7] I. CSISZÁR Information-type measures of diference of probability distributions and indirect observations, Studia Sci Math Hungar. 2 (1967), 299-318.

[8] P. J. DAVIs, Interpolation and Approxiamtion, Blaisdell Publishing Co., Boston. (1961).

[9] V. L. Gontscharoff, Theory of Interpolation and Approxiamtion of Functions, Gostekhizdat Moscow. (1954).

[10] L. HorvÁth, Inequalities corresponding to the classical Jensen's inequality, J. Math. Inequal. 3(2) (2009), 189-200.

[11] L. Horváth, K. A. KHAN AND J. PeČARIĆ, Cyclic refinements of the discrete and integral form of Jensen's inequality with applications, Analysis, Munich. 36(4) (2016), 253-263.

[12] L. Horváth, K. A. KhAN AND J. PeČARIĆ, Combinatorial improvements of Jensen's inequality, Monographs in Inequalities 8, Element, Zagreb, (2014).

[13] J. Jakšetić, Đ. PeČarić and J. PeČarić, Some properties of Zipf-Mandelbrot law and Hurwitz $\zeta$-function, Math. Inequal. Appl. 21(2) (2018), 575-584.

[14] J. Jakšetić And J. PeČArić, Exponential Convexity Method, J. Convex Anal. 20(1) (2013), 181197. 
[15] M. A. Khan, Đ. PeČarić And J. PeČArić, Bounds for Shannon and Zipf-mandelbrot entropies, Mathematical Method in Applied Sciences. 40(18) (2017), 7316-7322.

[16] M. A. Khan, Đ. PeČARIĆ And J. PeČAriĆ, On Zipf-Mandelbrot entropy, Computational and Applied Mathematics. 346 (2019), 192-204.

[17] S. KUllBACK, Information Theory and Statistics, J. Wiley, New York. (1959).

[18] S. Kullback AND R. A. LeIBler, On information and sufficiency, Annals Math. Statist. 22 (1951), $79-86$.

[19] A. LESNE, Shannon entropy: a rigorous notion at the crossroads between probability, information theory, dynamical systems and statistical physics, Mathematical Structures in Computer Science. 24(3) (2014), 63 pages. doi:10.1017/S0960129512000783.

[20] N. Mehmood, R. P. Agarwal, S. I. Butt And J. Pečarić, New generalizations of Popoviciutype inequalities via new Green's functions and Montgomery identity, J. Inequal. Appl. (2017), 2017:108.

[21] J. PeČARIĆ And J. Perić, Improvement of the Giaccardi and the Petrović Inequality and Related Stolarsky Type Means, An. Univ. Craiova Ser. Mat. Inform. 39(1) (2012), 65-75.

[22] J. Pečarić, F. Proschan and Y. L. Tong, Convex functions, Partial Orderings and Statistical Applications, Academic Press, New York, (1992).

[23] J. PeČARIĆ, M. PRALJAK AND A. WitKOWSKI, Linear operator inequality for $n$-convex functions at a point, Math. Inequal. Appl. 18 (2015), 1201-1217.

[24] C. E. Shannon, A mathematical theory of communication, Bull. Sept. Tech. J. (1948) 27, 370-423 and 623-656.

[25] D. V. Widder, Completely convex function and Lidstone series, Trans. Am. Math. Soc. 51 (1942), 387-398. 